\title{
PENDAMPINGAN STRATEGI PEMASARAN DIGITAL PRODUK MAKANAN DALAM MENJALANKAN BISNIS DI ERA NEW NORMAL DI KOTA BANDUNG
}

\author{
Arief Rahmana ${ }^{1)}$, Muchammad Fauzi ${ }^{2)}$, Annisa Maharani Suyono ${ }^{3)}$ \\ 1) Program Studi Teknik Industri, Fakultas Teknik, Universitas Widyatama, e-mail:arief.rahmana@widyatama.ac.id \\ 1) Program Studi Teknik Industri, Fakultas Teknik, Universitas Widyatama, e-mail:muchammad.fauzi@widyatama.ac.id \\ 1) Program Studi Teknik Industri, Fakultas Teknik, Universitas Widyatama, e-mail:annisa.maharani@widyatama.ac.id
}

\begin{abstract}
Abstrak
Kondisi perekonomian Indonesia saat ini terdampak oleh situasi pandemi Covid-19 akibatnya banyak pelaku usaha pada UMKM yang mengalami keterpurukan. Sementara itu, pemerintah berupaya untuk memulihkan perekonomian Indonesia melalui fase new normal. Dengan demikian, pelaku usaha harus bisa beradaptasi dengan berbagai perubahan tersebut. Diantaranya dengan mengembangkan usahanya melalui pemasaran digital yang mendukung agar produk yang dihasilkan bisa di akses dari rumah. Penyuluhan dan pendampingan perlu dilakukan bagi masyarakat sebagai pelaku usaha yang berada di Kelurahan Margasari Kecamatan Buah Batu Kota Bandung dalam menjalankan bisnisnya di era new normal saat ini. Kegiatan Pengabdian kepada Masyarakat $(\mathrm{PkM})$ ini diawali dengan survey lapangan oleh mahasiswa pada hari Rabu tanggal 10 Maret 2021 ke-6 UMKM. Pada tanggal 15 dan 16 Maret 2021 dilaksanakan penyuluhan Strategi Pemasaran Berbasis Digital untuk UMKM di Masa Pandemi Covid-19 dan pada tanggal 17 Maret 2021 dilaksanakan pendampingan langsung ke rumah warga yang menjalankan UMKM. Hasil dari kegiatan PkM 86,67\% menurut UMKM terbantu dengan adanya kegiatan PkM melalui; 86,67\% menurut UMKM mendapatkan pencerahan untuk mengembangkan usaha di masa Pandemi Covid19; $80 \%$ menurut UMKM paham tentang pemasaran produk dengan bantuan teknologi digital. 73,33\% menurut UMKM terbantu dengan pemanfaatan teknologi digital dalam mengembangkan UMKM.
\end{abstract}

Kata Kunci: strategi pemasaran, pemasaran digital, UMKM

\begin{abstract}
The current condition of the Indonesian economy is affected by the Covid-19 pandemic situation as a result of which many business actors at MSMEs are experiencing a downturn. Meanwhile, the government is trying to restore Indonesia's economy through a new normal phase. Thus, business actors must be able to adapt to these various changes. Among them by developing their business through digital marketing that supports the products produced can be accessed from home. Counseling and assistance need to be done for the community as business actors who are in Margasari Village, Buah Batu District, Bandung City in carrying out their business in the current new normal era. This Community Service (PkM) activity begins with a field survey by students on Wednesday, March 10, 2021, the 6th UMKM. On March 15 and 16, 2021, there was counseling on Digital-Based Marketing Strategies for MSMEs during the Covid-19 Pandemic and on March 17, 2021, direct assistance was carried out to the homes of residents who run MSMEs. The results of PkM activities are $86.67 \%$ according to MSMEs being helped by PkM activities through; $86.67 \%$ according to MSMEs got enlightenment to develop businesses during the Covid-19 Pandemic; $80 \%$ according to MSMEs understand product marketing with the help of digital technology. $73.33 \%$ according to MSMEs it was helped by the use of digital technology in developing MSMEs.
\end{abstract}

Keywords: marketing strategy, digital marketing, MSMEs. 


\section{PENDAHULUAN}

Kondisi perekonomian indonesia saat ini terdampak oleh situasi pandemi COVID 19. Hal ini terlihat pada kondisi pelaku bisnis di Indonesia. Banyak pelaku usaha pada UMKM yang mengalami keterpurukan terhadap kondisi saat ini. Sebelum terjadinya pandemi ini, sektor UMKM menyumbangkan kontribusi $60,3 \%$ terhadap total produk domestik brutto (PDB) Indonesia yang berdampak positif terhadap perekonomian Indonesia. Selain itu, tenaga kerja UMKM menyerap $97 \%$ total tenaga kerja diseluruh Indonesia. Namun, dampak pandemi covid bagi pelaku usaha UMKM yang bergerak dibidang kuliner dan penyedia kebutuhan sehari-hari mengalami penurunan. Hal tersebut juga berdampak pada sektor tenaga kerja. Terdapat sekurangnya 2,8 juta pekerja di PHK dan dirumahkan akibat berhentinya operasional perusahaan dimana mereka bekerja (Basuki, 2020). Sementara itu, ada beberapa sektor yang terdampak corona sehingga harus merumahkan atau melakukan PHK terhadap karyawan. Sektor-sektor tersebut yaitu perhotelan, restoran, alas kaki, ritel, farmasi, tekstil, dan transportasi darat. Kondisi ini diprediksi akan terus berlanjut hingga ditemukan vaksin covid-19. Demikian pula, dengan industri tekstil, sepatu atau alas kaki yang telah merumahkan atau PHK karyawan sebanyak 500 ribu orang, diikuti sektor retail 400 ribu orang, dan sektor farmasi 200 ribu orang (Fauziyah, 2020).

Sementara itu, pemerintah berupaya untuk memulihkan perekonomian indonesia melalui fase new normal. Hal ini dikarenakan kegiatan ekonomi memerlukan kepastian dan tidak boleh berhenti terlalu lama, karena beresiko menambah pengangguran dan mengarahkan ke kondisi resesi (Pambudi, 2020). Hal ini berlaku juga terhadap pelaku usaha di Indonesia, banyak sektor UMKM konvensional yang terpuruk dan mengalami kepasifan dalam bisnisnya di kondisi saat ini. Adanya fase new normal bagi pelaku usaha membantu bisnis beradaptasi dengan kecepatan yang diperlukan melalui strategi digitalisasi. Oleh karena itu, banyak pelaku usaha yang memasarkan produknya dari offline ke online, namun hanya sekitar
8 juta UMKM atau 13\% dari seluruh UMKM. Untuk mendukung pemanfaatan teknologi di sektor UMKM, Kementerian Koperasi dan UKM menargetkan tambahan 2 juta pelaku UMKM bisa menjalankan bisnis secara digital hingga akhir 2020 (Juminto, 2020). Denggan demikian, pemerintah berharap dengan penerapan kondisi new normal, ekonomi tetap berputar dan sektor industri tetap berjalan, serta pelaku usaha dapat menguasi teknologi digital dan mengikuti anjuran protokol kesehatan yang sudah ditetatpkan.

Pandemi COVID 19 menimbulkan dampak yang cukup besar bagi pelaku usaha UMKM di Jawa Barat. Berdasarkan data Dinas Koperasi dan Usaha Kecil Menengah (KUKM) Jabar, sekitar 37.200 UMKM di Jabar mengalami dampak secara langsung dari situasi saat ini. Bahkan, sekitar $40 \%$ pelaku usaha harus menutup usahanya secara total. Apabila UMKM terdampak, maka daya beli masyarakat di tingkat nasional maupun regional Jabar akan berpotensi mengalami penurunan (Fardi, 2020). Selain itu, produksi UMKM mengalami penurunan secara drastis karena pemasaran yang terbatas akibat kebijakan karantina wilayah dan daya beli masyarakat yang terus menurun, yang berakibat pada “Cash flow” UMKM jadi rendah. (Hartadji, 2020).

Sementara itu, salah satu sektor usaha yang berada di Jawa Barat, yaitu UMKM di Kelurahan Margasari Kecamatan Buah Batu Kota Bandung, mengalami dampak dari pandemi virus corona. Hal ini berimbas pada keberlangsungan perekonomian para UMKM. Namun, Pemerintah akhirnya memberlakukan kebijakan new normal atau tatanan baru yang memungkinkan berbagai bidang usaha dapat beroperasi secara bertahap di masa pandemi Covid-19. Kebijakan ini membawa peluang dan dampak positif bagi pebisnis, termasuk para pelaku UMKM yang telah siap membuka usahanya kembali. UMKM yang masih memiliki modal kerja sudah tentu siap memulai kembali usahanya. (Simanjorang, 2020).

Dengan demikian, pelaku usaha harus bisa beradaptasi dengan berbagai perubahan tersebut. Diantaranya dengan mengembangkan platform yang mendukung agar produk yang dihasilkan bisa di akses dari rumah. "Pengembangan platform digital sangat membantu karena sebagian besar orang lebih banyak 
di rumah, tapi tetap bisa melakukan kegiatan termasuk transaksi melalui platform digital. (Santoso, 2020).

Oleh karena itu, penyuluhan perlu dilakukan bagi masyarakat sebagai pelaku usaha yang berada Kelurahan Margasari Kecamatan Buah Batu Kota Bandung dalam menjalankan bisnisnya di era new normal saat ini. Hal ini berdasarkan survey kondisi UMKM di Kelurahan Margasari Kecamatan Buah Batu Kota Bandung, yang teridentifikasi mengalami permasalahan terkait, meliputi:

1. Keterbatasan pengetahuan masyarakat mengenai pemasaran produk secara digital

2. Keterbatasan pengetahuan masyarakat dalam dalam menjalankan strategi bisnis di era new normal

Secara garis besar solusi dari permasalahan yang telah dikemukakan adalah:

1. Memberikan informasi mengenai perubahan pola perilaku konsumen saat pandemik.

Salah satu upaya pencegahan terpaparnya COVID19 bagi masyarakat adalah menghindari perkumpulan orang dan ruang tertutup yang ramai (World Health Organization, 2020). Adanya upaya ini memberikan dampak yaitu perubahan perilaku konsumen yang lebih memilih untuk bertaransaksi melalui digital marketplace.

2. Memberikan paparan mengenai strategi dalam digital marketplace.

Perbelanjaan secara online semakin meningkat dan diprediksi akan tetap menjadi pilihan setelah pandemi ini berakhir. Dengan memberikan paparan mengenai digital marketplace, diharapkan UMKM dapat berjualan secara online. Strategi ini meliputi strategi pengembangan produk dan kemasan, sarana dan prasarana promosi, serta strategi komunikasi pemasaran secara online.

\section{METODOLOGI PENGABDIAN}

Metode pelaksanaan dilengkapi dengan bagan alir yang menggambarkan rencana jalannya PkM (Pengabdian kepada Masyarakat). Metode harus menjelaskan secara utuh tahapan penelitian yang jelas, luaran, indikator capaian yang terukur di setiap tahapan. Tahapan kegiatan PKM selengkapnya dapat dilihat pada Gambar 1.

\section{Identifikasi Masalah}

Permasalahan yang mendasari adanya kegiatan PkM ini adalah perubahan perilaku konsumen yang lebih memilih untuk bertaransaksi melalui digital marketplace pada masa pandemic Covid19. Hal tersebut yang mendasari diperlukannya memberikan penyuluhan kepada masyarakat terkait pencegahan terpaparnya Covid-19 dengan meningkatkan perekonomian karena terdampak Covid-19.

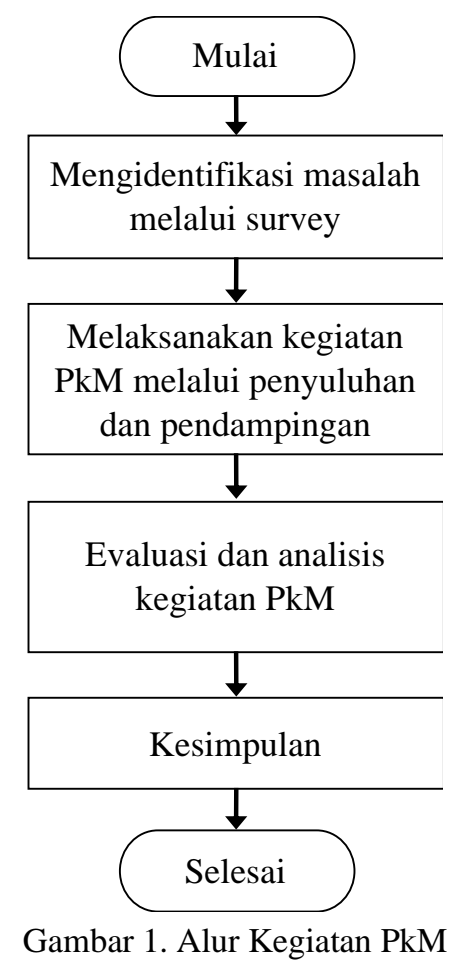

\section{Penyuluhan Digital Marketplace}

Setelah memperoleh perizinan dari wilayah setempat, dilaksanakan penyuluhan mengenai usaha meningkatkan perekonomian khususnya dengan berjualan pada digital marketplace. Hal ini bertujuan membuka pemikiran masyarakat terhadap potensi perubahan perilaku konsumen yang dapat dimanfaatkan untuk meningkatkan penjualan selama ini. Menurut (Artaya \& Purworusmiardi, 2021) digital marketplace dapat meningkatkan penjualan.

\section{Evaluasi dan Analisis Program}

Setelah seluruh kegiatan penyuluhan serta pemberian masker selesai, maka dilaksanakan kegiatan evaluasi. Evaluasi bertujuan untuk menilai sejauh program tersebut dapat 
dilaksanakan tepat sasaran. Hasil evaluasi kemudian digunakan untuk bahan analisis guna mendapatkan suatu langkah-langkah yang dapat diterapkan untuk kegiatan selanjutnya.

\section{PELAKSANAAN KEGIATAN}

Pelaksanaan kegiatan Penyuluhan dan Pendampingan Strategi Pemasaran Digital Produk Makanan Dalam Menjalankan Bisnis Di Era New Normal di Rumah Warga UMKM Kelurahan Margasari Kecamatan Buah Batu Kota Bandung. Pelaksanaan kegiatan ini dimulai dari hari Rabu 10 Maret 2021, Senin 15 Maret 2021 hingga 17 Maret 2021. Kegiatan ini dilakukan oleh tim Pengabdian kepada Masyarakat Program Studi Teknik Industri Universitas Widyatama yang terdiri dari tiga dosen dan tiga mahasiswa seperti pada Tabel 1 .

Tabel 1. Daftar Tim PkM

\begin{tabular}{clc}
\hline No & \multicolumn{1}{c}{ Nama } & Jabatan \\
\hline 1 & $\begin{array}{l}\text { Dr. Arief Rahmana, S.T., M.T., } \\
\text { CIPMP }\end{array}$ & Ketua \\
\hline 2 & Muchammad Fauzi, S.T., M.Log. & Anggota \\
\hline 3 & $\begin{array}{l}\text { Annisa Maharani Suyono, S.T., } \\
\text { M.M. }\end{array}$ & Anggota \\
\hline 4 & Ashry Amalia H 0518101010 & Mahasiswa \\
\hline 5 & Popy Primaviani 0518101015 & Mahasiswa \\
\hline 6 & Ikhsan Ahadi 0518101020 & Mahasiswa \\
\hline
\end{tabular}

\section{HASIL DAN PEMBAHASAN}

Kegiatan Pengabdian kepada Masyarakat ini dilakukan dengan melakukan survey terlebih dahulu oleh tim mahasiswa pada hari Rabu tanggal 10 Maret 2021 ke UMKM produk makanan di daerah Kelurahan Margasari Kecamatan Buah Batu Kota Bandung. Pada tanggal 15 dan 16 Maret 2021, tim memberikan penyuluhan melalui google meet dengan judul "Strategi Pemasaran Berbasis Digital untuk UMKM di Masa Pandemi Covid-19" oleh Dr. Arief Rahmana, S.T., M.T., CIPMP dan pada tanggal 17 Maret 2021, tim memberikan pendampingan langsung ke UMKM untuk menerapkan konsep fotografi pemasaran digital dan membuat akun promosi melalui instagram dan akun berjualan di marketplace oleh Muchammad Fauzi, S.T., M.Log.,
Annisa Maharani, S.T., M.M., Ashry Amalia, Popy Primaviani, dan Ikhsan Ahadi.

\section{Tahapan Survey}

Survey dilaksanakan pada tanggal 11 Maret 2021 ke-5 UMKM yang ditunjukkan pada Tabel 2.

Tabel 2. Daftar UMKM

\begin{tabular}{cll}
\hline No & & Profil UMKM \\
\hline 1 & Nama UMKM & : Sistik Mojang 39 \\
& Nama Pemilik & : Nur Aida \\
& Alamat & : Jl. Margaluyu RT08 RW09 \\
& & No. H008 \\
& Jenis Usaha & : Cheese Stick \\
\hline 2 & Nama UMKM & : Kue Basah Ayoe Pratiwi \\
& Nama Pemilik & : Ayoe Pratiwi \\
& Alamat & : Jl. Antajaya No 17 RT 04/04 \\
& Jenis Usaha & : Kue Basah dan Ulang Tahun \\
\hline 3 & Nama UMKM & : Ingin Catering \\
& Nama Pemilik & : Enung Nurhasanah \\
& Alamat & : Jl. Cipagalo Girang No.18 RT \\
& & 08/06 \\
& Jenis Usaha & : Catering \\
\hline 4 & Nama UMKM & : El's Salad \\
& Nama Pemilik & : Siti Samilah \\
& Alamat & : Jl. Margasari No. 188 RT \\
& & 04/10 \\
& Jenis Usaha & : Salad Buah \\
\hline 5 & Nama UMKM & : Rempeyek Bu Ai \\
& Nama Pemilik & : Bu Ai \\
& Alamat & : Jl. Gg. H. Patah No. A18 \\
& Jenis Usaha & : Rempeyek \\
\hline
\end{tabular}

\section{Hasil Survey Sistik Mojang 39}

Sistik Mojang 39 memiliki tiga varian rasa, yaitu keju, bawang, dan pedas. Dalam memasarkan cheese stick, Bu Nur memasarkan produk dengan cara mencari reseller untuk dijual kembali sehingga dapat memperluas jaringan pemasaran melalui kerabat dekat, tetangga, dan mulai mencoba memasarkan produk melalui media sosial seperti whatsapp, instagram dan shopee. Kendala yang dihadapi saat ini adalah:

1. Belum optimal dalam penggunaan media sosial.

2. Belum memiliki foto produk yang laik untuk dipasarkan.

3. Belum memiliki label pada kemasan.

4. Kemasan tidak dapat melindungi produknya pada saat pengiriman ke luar kota. 
Berikut adalah dokumentasi survey Sistik Mojang 39 yang ditunjukkan pada Gambar 2.

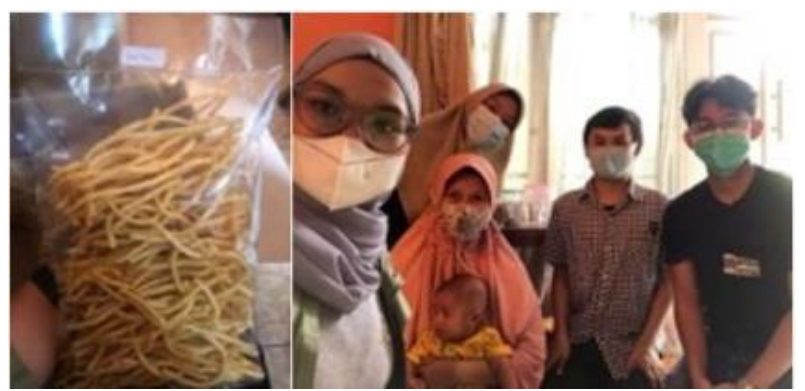

Gambar 2. Dokumentasi Survey Sistik Mojang 39

\section{Hasil Survey Kue Basah Bu Ayoe}

Kue Basah Ayoe Pratiwi saat ini memasarkan produknya melalui media sosial whatsapp dan instagram. Penjualan kue basah $\mathrm{Bu}$ Ayoe menggunakan sistem make to order atau Pre-Order (PO). Kendala yang dihadapi saat ini adalah:

1. Belum memiliki foto produk yang laik untuk dipasarkan.

2. Ingin memperluas jaringan pasar melalui marketplace.

\section{Hasil Survey Ingin Catering}

Ingin Catering saat ini memasarkan produknya melalui media sosial whatsapp dan instagram. Penjualan Ingin Catering menggunakan sistem make to order atau Pre-Order (PO). Kendala yang dihadapi saat ini adalah:

1. Belum memiliki foto produk yang laik untuk dipasarkan.

2. Belum memperluas jaringan pasar melalui marketplace.

Berikut adalah dokumentasi survey Ingin Catering yang ditunjukkan pada Gambar 3 dan 4 .

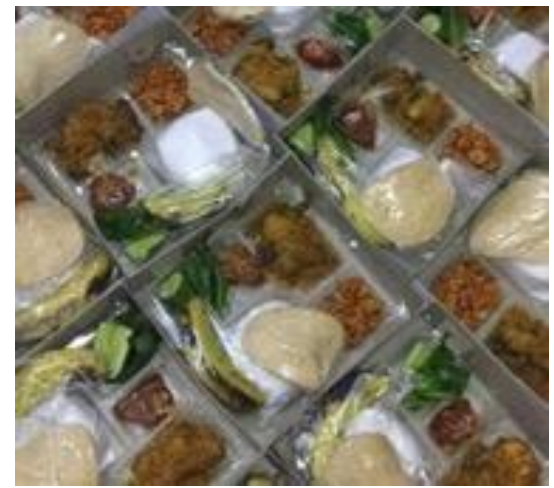

Gambar 3. Dokumentasi Survey Ingin Catering

\section{Hasil Survey El's Salad}

El's Salad saat ini menjual produknya melalui ojek online seperti gofood dan grabfood. Kendala yang dihadapi saat ini adalah:

1. Belum memiliki foto produk yang laik untuk dipasarkan.

2. Belum mempunyai logo untuk label produk.

3. Belum memiliki media sosial seperti instagram sebagai media promosi.

Berikut adalah dokumentasi survey El's Salad yang ditunjukkan pada Gambar 4.

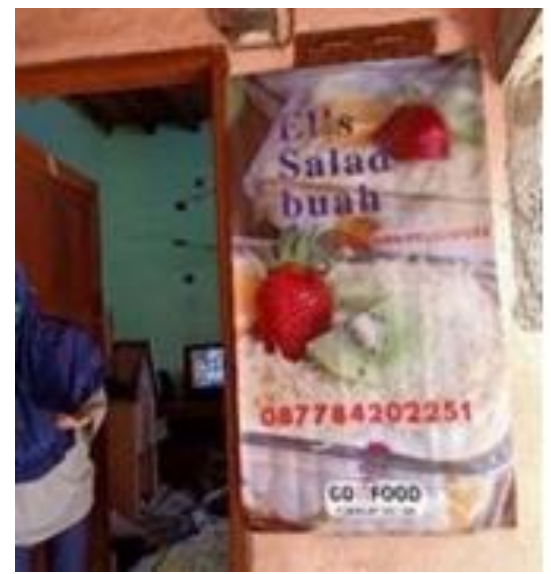

Gambar 4. Dokumentasi Survey El's Salad

\section{Hasil Survey Rempeyek Bu Ai}

Rempeyek $\mathrm{Bu} \mathrm{Ai}$ saat ini memasarkan produknya melalui whatsapp. Kendala yang dihadapi saat ini adalah:

1. Belum memiliki foto produk yang laik untuk dipasarkan.

2. Belum memiliki media sosial seperti instagram sebagai media promosi.

3. Belum memperluas jaring pasar melalui marketplace.

Berikut adalah dokumentasi survey Rempeyek Bu Ai yang ditunjukkan pada Gambar 5.

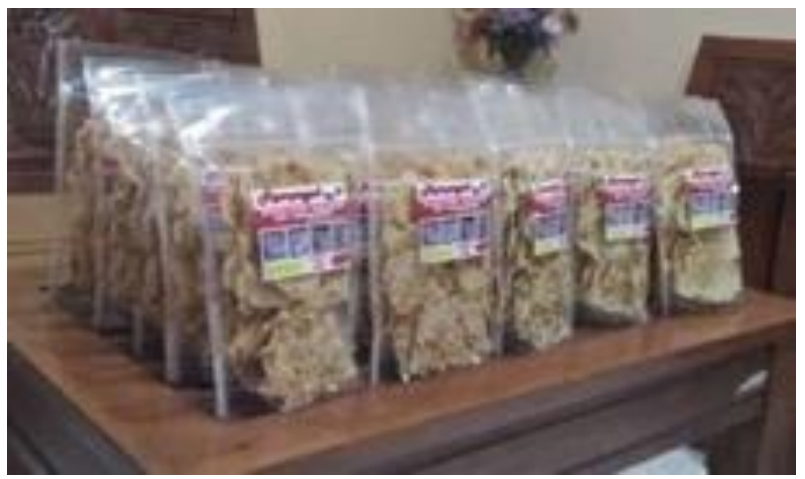

Gambar 5. Dokumentasi Survey Rempeyek Bu Ai 


\section{Tahapan Penyuluhan}

Pada tahap ini, tanggal 15 dan 16 Maret 2021 dilakukan penyuluhan melalui google meet seperti pada Gambar 6 dengan judul "Strategi Pemasaran Berbasis Digital untuk UMKM di Masa Pandemi Covid-19" oleh Dr. Arief Rahmana, S.T., M.T., CIPMP. Pada penyuluhan ini memberikan penjelasan tentang transformasi pemasaran tradisional ke era digital terutama masa Pandemi Covid-19 ini. Transformasi tersebut dipengaruhi oleh perilaku konsumen dalam kegiatan membeli secara online. Pemasaran tradisional adalah sebuah istilah strategi pemasaran yang memiliki beragam saluran periklanan, seperti iklan di media cetak, papan reklame, televisi, pamflet dan kampanye poster, hingga iklan siaran radio. Sedangkan pemasaran digital adalah aktifitas atau kegiatan pemasaran dengan serangkaian cara dan teknik yang menggunakan media digital yang bertujaan mendapatkan traffic, data, dan customer.

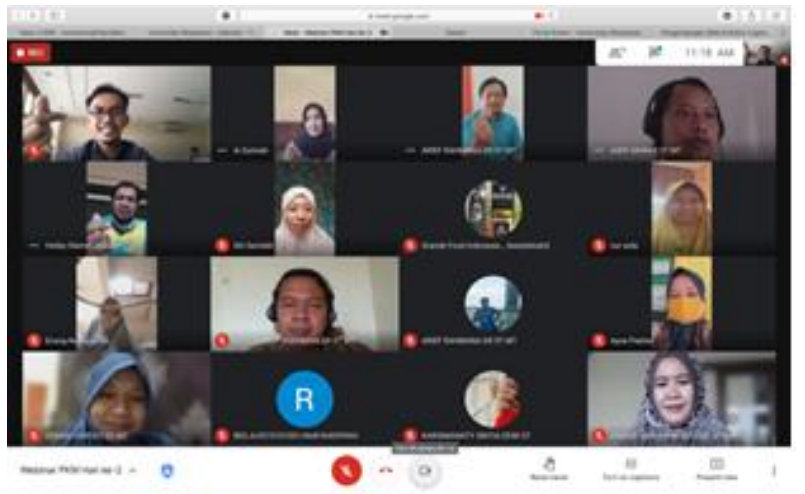

Gambar 6. Penyuluhan melalui google meet

Media digital yang dapat dipakai sebagai promosi seperti facebook, youtube, instagram, whatsapp business, line, dan tiktok. Pada penyuluhan ini juga menjelaskan tentang kelebihan dan kekurang menggunakan pemasaran digital, seperti yang ditunjukkan pada Tabel 3.

Startegi untuk menarik perhatian konsumen melalui media digital adalah dengan membuat desain dan foto produk yang menarik dan membuat konten yang viral, seperti contoh pada Gambar 7 menujukkan promosi bakso, tiny donut cereal, mini donut cereal, dan kelapa bakar menggunakan aplikasi tiktok yang viral.
Tabel 3. Kelebihan dan Kekurangan Pemasaran Digital

\begin{tabular}{cc}
\hline Kelebihan & Kekurang \\
\hline $\begin{array}{c}\text { Jangkauan pasar lebih luas } \\
\text { murah }\end{array}$ & Bisa ditiru \\
\hline $\begin{array}{c}\text { Biaya pemasaran lebih } \\
\text { terlihat cepat }\end{array}$ & Terlalu banyak pesaing \\
\hline Target bisa diatur & Tidak dilirik jika tidak \\
menarik
\end{tabular}
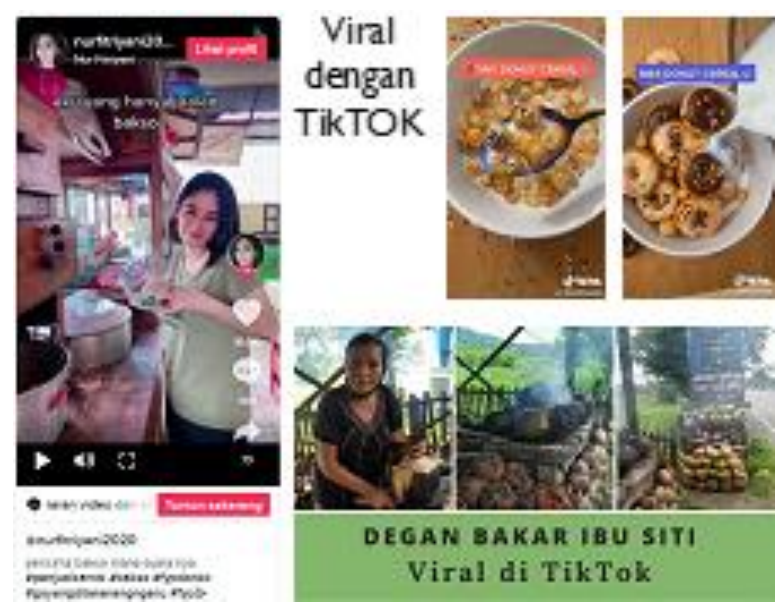

Gambar 7. Promosi menggunakan aplikasi tiktok

\section{Tahapan Pendampingan}

Pada tahap ini, tanggal 17 Maret 2021 dilakukan pendampingan ke rumah warga yang menjalankan UMKM untuk membuat akun instagram, shopee, foto produk, dan membuat label.

\section{Hasil Pendampingan Sistik Mojang 39}

Pendampingan pada Sistik Mojang 39 adalah membantu mengajarkan mengambil foto produk yang menarik, membuat promosi melalui media instagram, membuat label pada kemasan, dan memberi saran untuk menambah kemasan menggunakan bubble wrap atau mengganti kemasan menggunakan toples seperti pada Gambar 7 dan 8 . 


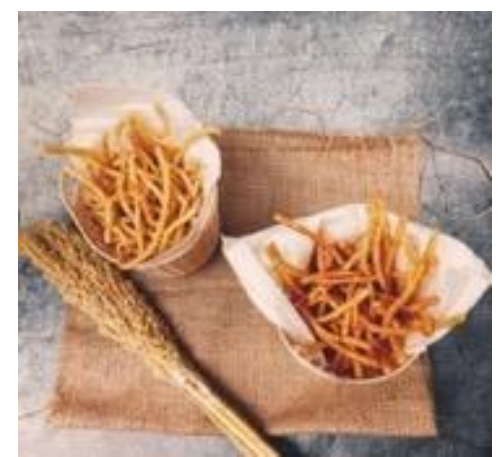

Gambar 7. Foto produk chees stick

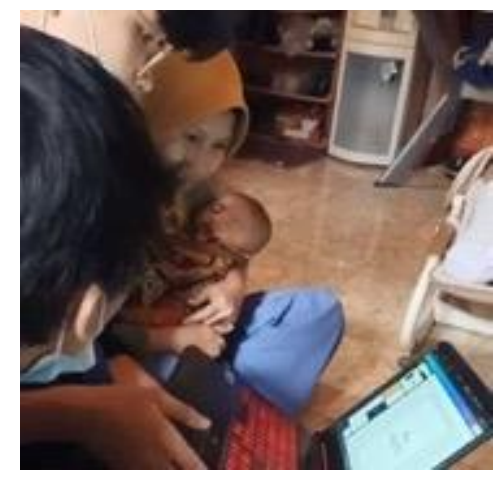

Gambar 8. Membuat label kemasan

\section{Hasil Pendampingan Kue Basah Ayoe Pratiwi}

Pendampingan pada Kue Basah Ayoe Pratiwi adalah membantu mengajarkan mengambil foto produk yang menarik dan membuat akun gofood seperti pada Gambar 9 dan 10.

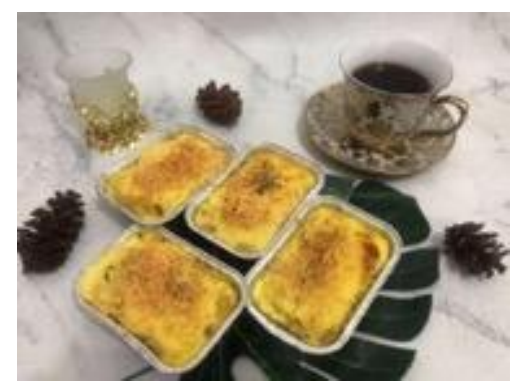

Gambar 9. Foto produk scootel

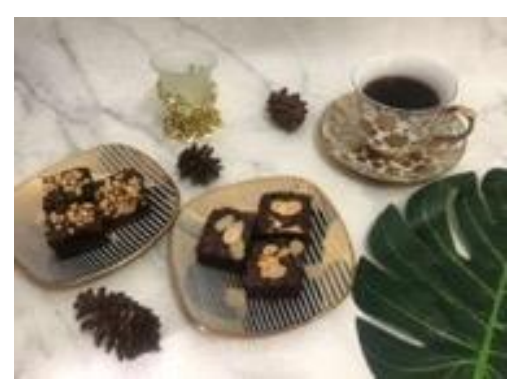

Gambar 10. Foto produk brownies

\section{Hasil Pendampingan Ingin Catering}

Pendampingan pada Ingin Catering adalah membantu mengajarkan membuat akun gofood untuk memperluas jaringan penjualan.

\section{Hasil Pendampingan El's Salad}

Pendampingan pada El's Salad adalah membantu mengajarkan mengambil foto produk yang menarik seperti pada Gambar 11.

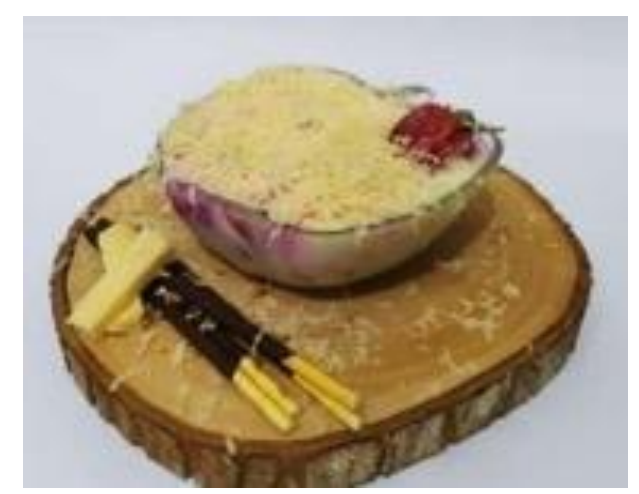

Gambar 11. Foto produk salad

\section{Hasil Pendampingan Rempeyek Bu Ai}

Pendampingan pada Rempeyek Bu Ai adalah membantu mengajarkan mengambil foto produk yang menarik seperti pada Gambar 12 dan pada Gambar 13 menunjukkan isi modul pengantar pembuatan akun marketplace shopee. Pada saat pendampingan kami membantu membuat akun shopee namun belum bisa aktif karena diperlukan scan buku tabungan pemilik belum bisa upload pada saat itu.

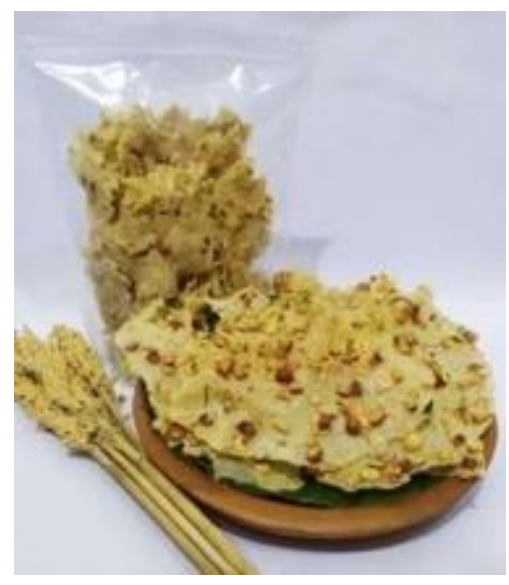

Gambar 12. Foto produk rempeyek 


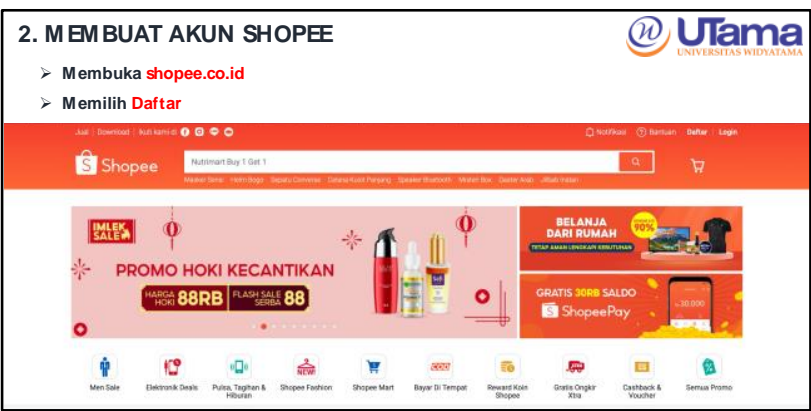

Gambar 13. Pembuatan akun shopee

\section{PENUTUP}

\section{Kesimpulan}

Berdasarkan hasil kegiatan Pengabdian kepada Masyarakat melalui kuesioner dapat diambil kesimpulan sebagai berikut:

1. $86,67 \%$ menurut UMKM terbantu dengan adanya kegiatan PkM melalui penyuluhan dan pendampingan ini.

2. $86,67 \%$ menurut UMKM mendapatkan pencerahan untuk mengembangkan usaha di masa Pandemi Covid-19.

3. $80 \%$ menurut UMKM paham tentang pemasaran produk dengan bantuan teknologi digital.

4. $73,33 \%$ menurut UMKM terbantu dengan pemanfaatan teknologi digital dalam mengembangakan UMKM.

\section{Saran}

Berdasarkan kegiatan penyuluhan dan pendampingan Pengabdian kepada Masyarakat ini, penulis memberikan saran untuk terus melanjutkan kegiatan pendampingan, karena para UMKM masih membutuhkan konsultasi dalam mengaktivasi dan menggunakan aplikasi promosi atau marketplace untuk berjualan serta sebagai sarana berdiskusi tentang strategi pemasaran produk.

\section{Ucapan Terima Kasih}

Penulis mengucapkan terimakasih kepada Universitas Widyatama, selaku pemberi dana dalam menjalankan kegiatan Pengabdian kepada Masyarakat ini, melalui hibah internal tahun 2021 dengan Nomor Kontrak No.36/SPC2/LP2MUTAMA/I/2021.

\section{DAFTAR PUSTAKA}

Basuki. (2020). Ekonomi Lumpuh! Ini Saran DR Basuki Ranto Agar UMKM Bisa Menjadi Pemulih Ekonomi Nasional. Diambil kembali dari industry.co.id: https://www.industry.co.id/read/72040/ekonom i-lumpuh-ini-saran-prof-dr-basuki-ranto-agarumkm-bisa-menjadi-pemulih-ekonominasional

Fauziyah, I. (2020). 7 Sektor Usaha Lesu, Kadin: 6,4 Juta Tenaga Kerja Terdampak Covid-19 Artikel ini telah tayang di Katadata.co.id dengan judul "7 Sektor Usaha Lesu, Kadin: 6,4 Juta Tenaga Kerja Terdampak Covid-19" , https://katadata.co.id/ekarina/berita/5eeb22d2 eaa93/7-se. Diambil kembali dari katadata.co.id:

https://katadata.co.id/ekarina/berita/5eeb22d2e aa93/7-sektor-usaha-lesu-kadin-6-4-jutatenaga-kerja-terdampak-covid-19

Pambudi, R. E. (2020). Ini Alasan New Normal 'Wajib' Dilakukan di RI pada 1 Juni. Diambil kembali dari cnbcindonesia.com: https://www.cnbcindonesia.com/news/2020051 8093037-4-159138/ini-alasan-new-normalwajib-dilakukan-di-ri-pada-1-juni

Juminto, M. S. (2020). Adaptasi UMKM saat New Normal. Diambil kembali dari jawapos.com: https://www.jawapos.com/opini/24/06/2020/ad aptasi-umkm-saat-new-normal/

Fardi. (2020). 37.200 UMKM Jawa Barat Sangat Membutuhkan, Pemerintah Harus Segera Kucurkan Bantuan. Diambil kembali dari pikiranrakyat.com: https://www.pikiranrakyat.com/ekonomi/pr-01634802/37200umkm-jawa-barat-sangat-membutuhkanpemerintah-harus-segera-kucurkanbantuan?page $=2$

Hartadji, K. (2020). Sebanyak 37.119 UMKM di Jabar terdampak COVID-19. Diambil kembali dari antaranews.com: https://www.antaranews.com/berita/1597614/se banyak-37119-umkm-di-jabar-terdampakcovid-19

Simanjorang, S. (2020). UMKM: Welcome New Normal, Goodbye Modal Kerja! Diambil kembali dari ekonomi.binis.com: 
https://ekonomi.bisnis.com/read/20200701/9/1 259952/umkm-welcome-new-normal-goodbyemodal-kerja

Santoso, P. (2020). UMKM Musti Ubah Cara Pandang, New Normal adalah Era Paradigma Baru. Diambil kembali dari pikiranrakyat.com: https://www.pikiran-rakyat.com/ekonomi/pr01395635/umkm-musti-ubah-cara-pandangnew-normal-adalah-era-paradigma-baru

Artaya, I. P., \& Purworusmiardi, T. (2021). Efektifitas Marketplace dalam Meningkatkan Konsentrasi Pemasaran dan Penjualan Produk bagi UMKM di Jawa Timur. ResearchGate. 